\title{
DIREITOS ECONÔMICOS, SOCIAIS E CULTURAIS DOS GRUPOS VULNERÁVEIS COMO NORMAS JUS COGENS NA JURISDIÇÃO DA CORTE INTERAMERICANA DE DIREITOS HUMANOS
}

\author{
THE ECONOMIC, SOCIAL AND CULTURAL RIGHTS OF VULNERABLE \\ GROUPS AS JUS COGENS NORMS AT THE INTER-AMERICAN COURT OF \\ HUMAN RIGHTS CASE LAW
}

\author{
${ }^{1}$ Débora Regina Mendes Soares
}

\section{RESUMO}

O artigo faz uma análise acerca de Direitos Humanos Econômicos, Sociais e Culturais de grupos vulneráveis integrarem o núcleo duro de normas universais e cogentes identificadas pelo Sistema Internacional de Proteção de Direitos Humanos como Jus Cogens, especificamente no âmbito da seara da jurisdição da Corte Interamericana de Direitos Humanos. A conclusão passa pelo exame de três dos julgamentos da referida Corte, a saber: o primeiro caso envolve a questão da violência de gênero (Caso da Penitenciária Miguel Castro Castro versus Peru); o segundo, envolve direitos e garantias aos seres humanos com deficiência e o combate às discriminações (Caso Ximenes Lopes versus Brasil); e o terceiro caso envolve direitos e garantias dos povos indígenas (Caso do Povo indígena Kichwa de Sarayaku versus Equador), identificando DESCs de grupos vulneráveis como Jus Cogens.

Palavras-chave: Jus cogens, Direitos econômicos, sociais e culturais, Grupos vulneráveis, Corte interamericana de direitos humanos

\begin{abstract}
This article analyses if Economic, Social and Cultural Rights of vulnerable groups could be incorporated at the hard core of universal and cogent norms described by the International System of Human Rights Protection as Jus Cogens, particularly at the jurisdiction of the InterAmerican Court of Human Rights. We've reached the conclusion through the review of three cases from said court: the first case concerns gender violence (Case of the Miguel CastroCastro Prison versus Peru); the second one concerns rights and guarantees of humans with disabilities and the fight against discrimination (Case Ximenes Lopes versus Brazil); and the third one is about rights and guarantees of indigenous people, recognizing ESCR of vulnerable groups as Jus Cogens
\end{abstract}

Keywords: Jus cogens, Economic, social and cultural rights, Vulnerable groups, Interamerican court of human rights

\footnotetext{
${ }^{1}$ Doutoranda em Direito pela Universidade Federal do Pará - UFPA, Pará (Brasil).

E-mail: deborasoaresadv@hotmail.com
} 


\section{Introdução}

O presente artigo tem o objetivo de fazer uma análise acerca de Direitos Humanos Econômicos, Sociais e Culturais (DESCs) integrarem o núcleo de normas identificadas como Jus Cogens, especificamente no âmbito da seara da jurisdição da Corte Interamericana de Direitos Humanos (CtIDH) e referentes à tutela de direitos dos grupos vulneráveis.

Logo se percebe que tal abordagem carrega dois assuntos demasiadamente complexos do direito internacional e em pleno vigor de desenvolvimento acadêmico e produção jurisprudencial nos órgãos internacionais: o Jus Cogens e o desenvolvimento dos DESCS dos grupos vulneráveis.

Apesar da limitação de desenvolvimento de tema tão denso em um artigo, tem o mesmo o propósito de identificar a tipificação de DESCs dos grupos vulneráveis como integrantes do núcleo duro de normas Jus Cogens, utilizando documentos normativos do direito internacional, conceitos da doutrina, decisões de órgãos internacionais e reflexões sobre alguns importantes julgados da CtIDH.

Foi, então, o artigo dividido em 5 (cinco) tópicos, a saber: no primeiro, traz algumas noções sobre conceito de normas Jus Cogens no plano Internacional; no segundo, considerações sobre o desenvolvimento dos DESCs; no terceiro tópico, analisa o julgamento no Caso da Penitenciária Miguel Castro Castro versus Peru e o combate à violência de gênero; no quarto, do Caso Ximenes Lopes versus Brasil e o combate às discriminações odiosas aos seres humanos com deficiência; e no quinto tópico, do Caso do Povo indígena Kichwa de Sarayaku versus Equador, sobre os direitos e garantias dos povos indígenas.

\section{Considerações sobre Jus Cogens e o conceito de universalidade dos direitos humanos}

O conceito de Jus Cogens é baseado na concepção do direito internacional dos direitos humanos, como o conjunto de direitos e faculdades que protegem a dignidade do ser humano com garantias internacionais institucionalizadas, criando obrigações para os Estados respeitarem e garantirem tais direitos a todos os seres humanos sob sua jurisdição, configurando o Jus Cogens como o núcleo duro inderrogável e imperativo em todos os níveis de proteção de tais direitos.

As normas integrantes do Jus Cogens não existem somente em razão de construção doutrinária ou de decisões judiciais na comunidade internacional. Estão expressamente previstas e protegidas na Convenção de Viena como 'Normas Imperativas de Direito 
Internacional Geral', dispondo os seus artigos 53 e 64 sobre a existência, validade e efeitos de tais normas, ressaltando as características imperativas e inderrogáveis e com primazia na interpretação e capacidade de anular outras normas que com elas antagonizem.

A Convenção Americana de Direitos Humanos (CADH) também destaca normas Jus Cogens, quando em seu artigo 27, que trata de suspensão de garantias, regula que nem mesmo em caso de guerra, de perigo público ou situação que ameace o Estado pode este suspender determinadas normas que lhe impõe o direito internacional, e nem podem, em nenhuma hipótese, praticar atos fundados em discriminação de raça, cor, sexo, idioma, religião ou origem social.

Normas Jus Cogens não são regras dispositivas, não estão sujeitas à derrogação conforme o arbítrio dos Estados e nem ao princípio contratual do pacto sunt servanda. Carregam conceito material com valores absolutos e fundamentais na ordem pública internacional, a exemplo do conteúdo principiológico do artigo $2^{\circ}$ da Carta da Organização das Nações Unidas. Assim, quando falamos em normas Jus Cogens, estamos diante de normas com superior qualidade material em seu conteúdo, abrangência universal, poder de efeitos erga omnes e de anulação de outras normas, numa clara existência de hierarquia normativa de normas do direito público internacional.

Vejamos alguns emblemáticos precedentes judiciais internacionais que reconhecem normas Jus Cogens:

Em 1951, a Corte Internacional de Justiça, no Parecer Consultivo de 28/05/1951 sobre as reservas à Convenção de Prevenção e Repressão ao crime de Genocídio, firmou jurisprudência sobre a universalidade e não possibilidade de reservas às regras de Jus Cogens, o que Ramos afirma ser um marco no direito internacional dos direitos humanos"1:

Na Opinião Consultiva n. 18/1992, referente à questão dos imigrantes ilegais, a CtIDH firmou que a não-discriminação em conjunto com a igualdade, são elementos básicos indispensáveis à proteção dos Direitos Humanos, e, da suprema importância desses valores, nasce a obrigação dos Estados em combater qualquer espécie de conduta discriminatória e, principalmente, em revertê-las, por meio das chamadas ações afirmativas, expressando que tratam-se de princípios de eficácia erga omnes, de forma a alcançar todas as pessoas que estejam no território e sob a jurisdição de um determinado Estado, não importando se nacionais ou estrangeiros, ainda que em situação irregular.

\footnotetext{
${ }^{1}$ RAMOS, André de Carvalho. Processo Internacional de Direitos Humanos. $4^{\text {a }}$ ed. São Paulo: Saraiva, 2015, p. 101 .
} 
O Tribunal de Justiça da União Europeia também valora normas Jus Cogens, e o caso Yassin Abdullah Kadi versus Council of the European Union and Commission of the European Communities, de 2001, tornou-se célebre por implicar um controle de legalidade de resoluções do Conselho de Segurança da ONU. O caso envolveu ponderação entre a proteção de direitos fundamentais das comunidades europeias e a obrigação de cooperação internacional no marco das Nações Unidas para o combate ao terrorismo, sendo a decisão expôs que o Tribunal possui competência para aferir, de forma indireta, a legalidade das resoluções do Conselho de Segurança da ONU no que diz respeito às normas Jus Cogens, afirmando que essas pertencem a um conjunto de regras superiores de direito internacional público, obrigatórias para todos os sujeitos de direito internacional, incluindo os órgãos das

Nações Unidas, e da qual nenhuma derrogação é possível ${ }^{2}$.

Para Cançado Trindade, o conceito de Jus Cogens transcende o âmbito dos direitos dos tratados, sendo uma responsabilidade internacional dos Estados de modo a alcançar o direito internacional geral e os próprios fundamentos da ordem jurídica internacional ${ }^{3}$. A propósito, citar produção acadêmica e jurisprudencial acerca dos Jus Cogens passa, necessariamente, pela referência teórica desse jurista, célebre por reiterar em seus votos a convicção de que estamos no atual processo histórico de promover a humanização do direito internacional, de buscar a consolidação do 'Novo Jus Gentium do século XXI', o 'Direito Internacional para a Humanidade', que apresenta as características da consciência humana voltada para os fundamentos e evolução do direito internacional dos direitos humanos; do ser humano como sujeito do direito internacional; da expansão e convergência dos regimes jurídicos de proteção internacional; e da efetiva vigência do Jus Cogens com a tendência de ampliação em seu conteúdo material ${ }^{4}$.

Apesar da positivação na Convenção de Viena e de decisões nos diversos Tribunais Internacionais, tal 'núcleo duro de normas' não tem aceitação pacífica na doutrina, havendo

\footnotetext{
2 TRINDADE, Otávio Augusto Drummond Cançado. A Carta das Nações Unidas. Uma leitura constitucional. Belo Horizonte: Del Rey, 2012, p.173-177.

3 Cf. voto fundamentado de Cançado Trindade na sentença do Caso Massacre Plan de Sánchez versus Guatemala, julgado pela CtIDH em 29/04/2009, que tratou de graves violações perpetradas por uma política genocida daquele país, realizada com intenção de aniquilar o povo indígena Maya. Disponível em: http://www.corteidh.or.cr/docs/casos/articulos/seriec_105_esp.pdf. Acesso em: 07 jul. 2015.

${ }^{4}$ TRINDADE, Antonio Augusto Cançado. A Humanização do Direito Internacional. Belo Horizonte: Del Rey, 2006, p.3-29. Ver também: Id, El Ejercicio de La Función Judicial Internacional. Belo Horizonte: Del Rey, 2011, onde constam importantes julgamentos da CtIDH e referências ao conteúdo dos votos do jurista.
} 
quem exalte a sua importância e efetividade pelos tribunais internacionais e quem negue a pretensão de universalidade de direitos humanos ${ }^{5}$.

\subsection{Jus Cogens e seu conceito universal.}

A abordagem sobre Jus Cogens remete à compreensão de universalidade de direitos humanos, uma vez que inerente ao próprio conceito daquelas normas. Obviamente, sem a pretensão de desenvolvimento sobre o tema, cumpre tão somente esclarecer sobre a concepção que se tem por adequada, haja vista que DESCs de grupos vulneráveis remetem às questões ligadas às particularidades culturais.

Acredita-se, pois, que Donnelly ${ }^{6}$ oferece uma adequada interpretação acerca da 'universalidade' dos direitos humanos, compatíveis com as referências teóricas utilizadas no trabalho, na compreensão de que compatibilidade não significa plena convergência. Donnelly traz o enfoque da universalidade dentro de um contexto mundial, com ênfase no instrumento jurídico internacional fundamental da universalidade dos direitos humanos, qual seja, a Declaração Universal dos Direitos Humanos, com destaque, também, para a Declaração de Viena, de 1993 e seu Programa de Ação, que afirma a natureza universal dos direitos humanos $^{7}$. E, o assunto deve ser aqui tratado, ainda que de forma incidental, pois apesar de ter o enfoque no Sistema Interamericano de Proteção dos Direitos Humanos (SIPDH), versa sobre conceitos de direitos universais diante de determinadas particularidades, como a tradição cultural dos povos indígenas.

Donnelly parte da premissa de que os direitos humanos, como um projeto político internacional, estão ligados às reivindicações universais. Contrapõe a concepção de pretensão de universalidade de direitos humanos no sentido de simbolizar a arrogância do imperialismo cultural do mundo ocidental e tentativa de universalizar suas próprias crenças, procurando atribuir os sentidos em que os direitos humanos universais podem ser relativizados, daí o

\footnotetext{
${ }^{5}$ Teixeira apresenta sua teoria pluriversalista do direito internacional, criticando que os modelos universalistas de regulação jurídica da política internacional, a exemplo do apresentado no processo de formação da ONU, pecam pela pretensão de 'universalizar o particular'. TEIXEIRA, Anderson Vichinkeski. Teoria Pluriversalista do Direito Internacional. São Paulo: Martins Fontes, 2011, p.248-251.

${ }^{6}$ DONNELLY, Jack. The Relative Universality of Human Rights. Human Rights Quarterly, v. 29, n. 2, 2007, p. 281-306.

7 Como lembra Cançado Trindade, a concepção holística dos direitos humanos impulsionou as I e II Conferências Mundiais dos Direitos Humanos (a primeira em 1968, no Teerã, e a segunda em 1993, em Viena) consagrando os compromissos de se formar a integração e efetivação dos direitos humanos numa seara global. TRINDADE, Antônio Augusto Cançado. O Legado da Declaração Universal dos Direitos Humanos e sua Trajetória ao Longo das Seis Últimas Décadas (1948-2008). In: GIOVANNETTI, Andrea (Org.) 60 anos da declaração universal dos direitos humanos: conquistas do Brasil. Brasília: Fundação Alexandre de Gusmão, 2009 , p.13.
} 
jurista utilizar a expressão 'relativa universalidade' dos direitos humanos, na certeza de que qualquer pretensão de universalidade absoluta, sem levar em conta a realidade antropológica e ontológica, são empiricamente, filosoficamente e politicamente indenfensáveis.

Assim, os direitos humanos universais integram espaço considerável para o nacional, o regional, o cultural, e outras formas de diversidades e particularidades, defendendo Donnelly uma forma de universalismo que também permite espaço substancial para importantes reivindicações de relativismo.

A universalidade conceitual é identificada na própria idéia de direitos humanos, ou seja, na universalidade substantiva, com a noção de que são os direitos humanos universais e inalienáveis por serem ínsitos ao seres humanos, e a questão de todos ainda gozarem desses direitos não compromete o conceito de universalidade substantiva.

O autor destaca que até os dias atuais, os direitos humanos continuam a ser a única forma comprovada de assegurar a dignidade nas sociedades dominadas pelos mercados e Estados, e merece séria atenção os argumentos no sentido de que outro Estado, sociedade ou cultura possam desenvolver mecanismos alternativos e eficazes para proteger ou perceber a dignidade humana no mundo contemporâneo, até mesmo porque, invariavelmente, tais argumentos são provenientes de elites repressivas e/ou de seus seguidores. Assim, para o autor, qualquer que seja a cultura, economia e recursos religiosos, morais, legais e políticos de uma sociedade, é a universalidade dos direitos humanos o caminho para fornecer soluções atraentes para combater as ameaças sistêmicas mais caras à dignidade da pessoa humana.

Revela que, a partir das Declarações Internacionais, os movimentos de justiça social e de oposição política têm cada vez mais adotado a linguagem universal dos direitos humanos, com um número crescente de novas questões internacionais que incluem sérios problemas sobre migração, comércio, finanças mundiais, acesso para produtos farmacêuticos, etc., todos enquadrados como questões de direitos humanos. E, um número mais crescente de países inserem os direitos humanos como sinônimo de sua expressão política contemporânea, sendo que até mesmo países reconhecidamente truculentos no modo de conduzir questões de direitos humanos já buscam adotar parâmetros internacionalmente reconhecidos, como condição inescapável para seu reconhecimento como potência mundial e para conferir legitimidade à sua política nacional e internacional.

Não é razoável reconhecer que as declarações universais de direitos humanos iriam trazer a mesma qualidade ou nível de implementação dos direitos declarados a todas as 
sociedades do planeta, mas sim, pretender particulares formas de implementação de tais direitos para cada sociedade, de acordo com suas culturas e concepções, a permitir que os seres humanos, individual e coletivamente, possuam espaço considerável para moldar os direitos universais ao seu modo particular. Porém, adverte Donnelly que, afrontar ao chamado 'mínimo ético irredutível' compromete a dignidade da pessoa humana, e, ainda que em nome da cultura, importará em violação aos direitos humanos, sendo repelida a radical corrente relativista que concebe a cultura como fonte única de validade de um direito ou regra moral.

Maniglia ${ }^{8}$ aponta o marco e a notória destinação 'a todos' da Declaração Universal dos Direitos Humanos, o que também foi consagrado nos múltiplos posteriores documentos internacionais. E que, os fenômenos da globalização, de efervescência cultural e política, as mutabilidades sociais e consagração dos novos direitos das minorias étnicas e raciais, das pessoas com deficiência, das mulheres, a regulamentação do direito ambiental e as relações de consumo, etc., provocaram um repensar nos direitos humanos e exigiram demandas para a efetivação local desses novos direitos, o que ensejou posturas relativistas, com países e aglomerados populacionais olhando 'para si próprio', porém, mantendo no interior uma 'ideologia universal humanista'.

A autora cita que a questão cultural, social, religiosa e política têm sido variáveis para questionar o caráter universalista dos direitos humanos, e que os fatos históricos, as análises de formação colonial, a 'europeização' de modelos, as crises globais, os sistemas de corrupção tornam a implementação universal dos direitos humanos uma incerteza e alvo de críticas.

Encontramos algumas classificações sobre universalismo e relativismo, inclusive apresentando 'graus' de intensidade (fraco/forte) ${ }^{9}$, que se localizam entre as concepções ditas absolutas no sentido de que o universalismo seria a imposição dos valores ocidentais que desprezaria os povos, suas histórias e culturas, até a no sentido de que o relativismo só se prestaria a encobrir graves violações de direitos humanos praticadas por chefes de Estados tiranos. Aqui, realmente não cabe abordar tais classificações.

Elege-se a perspectiva definida por Donnelly, sob argumento de que universalidade é o pressuposto da consagração dos direitos humanos proclamados nos instrumentos

\footnotetext{
${ }^{8}$ MANIGLIA, Elisabete. Direitos humanos: entre o relativismo e o universalismo. Ponderações e justificações das correntes em tempos hodiernos. In: LOPES, Ana Maria D’Ávila; MAUÉS, Antonio Moreira. A eficácia nacional e internacional dos direitos humanos. Rio de Janeiro, Lumen Juris, 2013, p.74-75.

${ }^{9}$ Flávia Piovesan observa que, adotando a lição de Donnely, conclui-se que a Declaração de Direitos Humanos (Viena, 1993) acolheu a corrente do 'forte universalismo' ou 'fraco relativismo cultural'. PIOVESAN, Flávia. Direitos Humanos e o Direito Constitucional Internacional. 15ª ed. São Paulo: Saraiva, p. 232.
} 
internacionais, e não um argumento absoluto e determinante com aplicação igualitária de todos os direitos e da mesma forma em todas as sociedades, e, defende-se a identificação, pelos organismos internacionais, de um 'mínimo ético irredutível' que não pode ser violado por comprometer de forma intolerável a dignidade humana, até mesmo porque o presente artigo busca a identificação de DESCs de grupos vulneráveis inseridos no núcleo duro de direitos universais.

\section{Breves considerações sobre o desenvolvimento dos DESCs.}

Encontramos fontes normativas internacionais dos DESCs nas Cartas das Nações Unidas, de 1945; na Declaração Americana dos Direitos e Deveres do Homem, de 1948; na Carta da Organização dos Estados Americanos (OEA), de 1948; na Declaração Universal dos Direitos Humanos, de 1948; na Convenção Europeia sobre Direitos Humanos, de 1953; no Pacto Internacional sobre Direitos Civis e Políticos e no Pacto Internacional sobre Direitos Econômicos, Sociais e Culturais, de 1969; na Convenção Americana sobre Direitos Humanos, de 1969; na Carta Africana de Direitos Humanos e dos Povos, de 1986; no Protocolo adicional à Convenção Americana sobre Direitos Humanos em matéria de DESCs (Protocolo de San Salvador), de $1998^{10}$.

Na II Conferência Mundial de Direitos Humanos (Viena, 1993) houve debates tensionados entre os países e severas críticas sobre a universalidade dos direitos humanos e questões sobre especificidades culturais, sociais, religiosas, políticas, bem como acerca do monitoramento da proteção de direitos humanos em cada país, questões de soberania nacional, supremacia das leis internacionais e implementação na jurisdição nacional.

No entanto, o Programa de Ação adotado nesta Conferência acabou por destacar a universalidade e indivisibilidade dos direitos humanos ${ }^{11}$ e ênfase nos mecanismos de proteção aos grupos denominados vulneráveis e sociedades excluídas, reconhecendo que todos os direitos humanos decorrem da dignidade e do valor inerentes à pessoa humana e que esta é o

\footnotetext{
${ }^{10}$ A Declaração de Quito (Equador) foi proclamada em 1998, por ONGs, redes, organizações sindicais ligadas aos direitos humanos de promoção e desenvolvimento dos povos indígenas e da defesa dos direitos da mulher. Em seu artigo 26, dita que os conteúdos dos DESC e as obrigações que lhes correspondem têm sido elaboradas em vários documentos e por várias instituições, incluídos nos Princípios de Limburgo e Maastricht, na Declaração de Bangalore e nos Comentários e Observações do Comitê do Pacto Internacional dos Direitos Econômicos, Sociais e Culturais. Disponível em: http://www.faders.rs.gov.br/legislacao/6/30. Acesso em: 08 jul. 2015.

${ }^{11}$ Vale conhecer o estudo realizado por Cristina Terezo acerca dos travaux preparatoires dos Pactos Internacionais sobre os Direitos Civis e Políticos e DESCs e os motivos que ensejaram reconhecer direitos humanos em dois textos normativos distintos. TEREZO, Cristina Figueiredo. Sistema Interamericano de Direitos Humanos: pela defesa dos direitos econômicos, sociais e culturais. Curitiba: Appris, 2014, p. 25-47.
} 
sujeito central dos direitos humanos e das liberdades fundamentais, bem como realçando que a Declaração Universal constitui um padrão comum a ser seguido por todos os povos e por todas as nações, reafirmando a consagração dos DESCs no âmbito internacional, e a igualdade de direitos e autodeterminação dos povos, da paz, da democracia, do desenvolvimento, de melhores padrões de vida e de solidariedade, e que, por força do direito dos povos à autodeterminação, escolhem livremente o seu estatuto político e prosseguem livremente o seu desenvolvimento econômico, social e cultural.

Assim, todos os Direitos Econômicos, Sociais e Culturais, ou melhor, todos os grupos de direitos humanos "são universais e podem ser gozados por todos os seres humanos, sendo que o seu exercício deverá obedecer a determinados critérios e dependerá da situação fática do indivíduo"12.

Destaca Lazarte ${ }^{13}$ que no SIPDH (SIDH), são três os instrumentos que abordam a temática dos DESCs dentro da Organização dos Estados Americanos (OEA): a Declaração Americana dos Direitos e Deveres do Homem, o Protocolo de San Salvador e a Convenção Americana de Direitos Humanos. E que, enquanto o Protocolo de San Salvador permite a judicialização somente nos casos referentes à liberdade sindical e ao direito à educação, a Convenção Americana de Direitos Humanos (CADH), em seu artigo 26 sobre DESCs, alude ao desenvolvimento progressivo de tais direitos ${ }^{14}$.

Os DESCs são norteados pelos princípios da progressividade e da não retroatividade $^{15}$, pois que uma vez declarados não podem ser suprimidos, sustentados na

\footnotetext{
${ }^{12}$ Id., p.55-56.

${ }^{13}$ LAZARTE, Renata Bregaglio. ¿Verdadera indivisibilidad? Las consencias de las judicialización indirecta de los derechos económicos, sociales y culturales em el Sistema interamericano de derechos humanos. In: LOPES, Ana Maria D’Ávila; MAUÉS, Antonio Moreira. A eficácia nacional e internacional dos direitos humanos. Rio de Janeiro, Lumen Juris, 2013, p. 257-290.

${ }^{14}$ Burgorgue-Larsen e Úbeda de Torres comentam que, por um longo tempo, a CtIDH não se pronunciou sobre o escopo do artigo 26 da CADH, e citam o landmark Caso Acevedo Buendia e outros (demitidos e aposentados da controladoria) versus Peru, de 2009, como um 'extraordinário julgamento' que deflagrou o real escopo do art. 26 da CADH, trazendo a certeza da justiciabilidade dos DESCs no sistema interamericano e a imposição de progressiva implementação desses direitos. BURGORGUE-LARSEN, Laurence; ÚBEDA DE TORRES, Amaya. The Inter-American Court of Human Rights: case law and commentary. Oxford: Oxford University Press, 2011, p. 620.

${ }^{15}$ Cf. Resolução 2.074 da OEA (XXXV-O/05) e artigo 29, 'c' da Declaração de Quito de 1998, que vedam ao Estado a implementação de políticas ou disposições regressivas, entendendo por todas aquelas que tenham por objeto e como efeito a diminuição do estado de gozo dos direitos humanos. Vale verificar o conteúdo da OC 17/2002, solicitada pela CIDH, sobre a condição jurídica e os direitos humanos das crianças (p.87). Disponível em: http://www.corteidh.or.cr/docs/opiniones/seriea_17_esp.pdf. Acesso em: 14 jun. 2015. E, também, conhecer o voto em separado do Juiz Rodolfo Piza Escalante proferido na OC 4/1984, solicitada pela Costa Rica, sobre proposta de emenda constitucional para naturalização provisória. Disponível em: http://www.corteidh. or.cr/docs/opiniones/seriea_04_esp.pdf. Acesso em: 14 jun. 2015.
} 
característica de indivisibilidade e interdependência dos direitos humanos ${ }^{16}$, na compreensão de que são por demais tênues os limites entre as categorias de direitos humanos, não raro ocorrendo violação de direitos civis e políticos acarretam consequentemente violações aos DESCs, e vice versa.

Também o artigo $2^{\circ}(1,2)$ do Pacto Internacional sobre Direitos Econômicos, Sociais e Culturais (PIDESC) ressalta a progressividade dos DESCs, afirmando que cada Estado compromete-se a adotar medidas (tanto por esforço próprio como pela assistência e cooperação internacionais e principalmente nos planos econômico e técnico) até o máximo de seus recursos disponíveis, visando a assegurar, progressivamente e por todos os meios apropriados, o pleno exercício dos DESCs, inclusive com adoção de medidas legislativas, e que os direitos enunciados no Pacto serão exercidos sem qualquer tipo de discriminação ${ }^{17}$.

Pode haver questionamento acerca da impossibilidade de DESCs figurarem como normas Jus Cogens, já que tais direitos dependeriam de implementação conforme a disponibilidade de recursos dos Estados, possibilitando, assim, escusas em observar regras Jus Cogens. Ocorre que, como bem se extrai do conteúdo da Declaração de Quito, de 1998, são autoaplicáveis e não progressivos determinados direitos humanos, especialmente aqueles identificados por 'mínimo irredutível'. Vários direitos humanos, sejam políticos, civis ou DESCSs, devem ser garantidos pelos Estados de forma imediata, sendo admissível somente em caráter de excepcionalidade que um Estado invoque uma temporária inobservância de cumprimento dos mesmos, nos casos de caos social e econômico, motivações que serão devidamente analisadas nos diálogos interativos com o Comitê DESCs, inclusive se as escusas apresentadas são de boa fé ${ }^{18}$.

\footnotetext{
${ }^{16}$ Burgorgue-Larsen e Úbeda de Torres destacam o leading case do sistema europeu, caso AIREY, de 1979, onde a Corte Europeia de Direitos Humanos realizou ponderação, entendendo que apesar da Convenção Europeia sobre Direitos Humanos consagrar essencialmente os direitos civis e políticos (na época), muitos deles surtiam impactos de natureza social ou econômica, não havendo, assim, uma clara distinção entre as duas categorias de direitos. Com o decorrer do tempo e a crescente atenção dada aos DESCs, foram incorporados alguns direitos à Convenção Europeia, tais como os consagrados pelo Protocolo I: direito à propriedade privada (artigo 1) e direito à educação (artigo 2). Op.cit., p.614-615.

${ }^{17}$ E se aplica o conceito amplo trazido por BRITO FILHO no sentido que "qualquer ação ou omissão de uma pessoa, intencional ou não, consciente ou não, que concretamente viole o princípio da igualdade e implique exclusão deve ser considerada discriminação". BRITO FILHO, Jose Claudio Monteiro de. Assegurando o gozo dos direitos em condições de igualdade: direitos humanos das pessoas com deficiência. In: BELTRÃO, Jane Felipe; BRITO FILHO, Jose Claudio Monteiro de; GÓMEZ, Itziar; PAJARES, Emilio; PAREDES, Felipe; ZÚÑIGA, Yanira (Coords.). Derechos humanos de los grupos vulnerables, 2014, p.73-87. Disponível em: http://www.upf.edu/dhes-alfa/materiales, p.81. Acesso em: 09 mai. 2015.

${ }^{18}$ TEREZO, op.cit., p. 60-61.
} 
E, obviamente, tal exceção parte da compreensão de que, ainda que escassos, todos os recursos disponíveis deverão ser investidos na construção de condições para o exercício dos direitos humanos considerados 'mínimos e irredutíveis', como o da alimentação, saúde (e acesso à medicação e à ciência e tecnologia disponível para provê-la). A propósito, lembra-se que, conforme explicita o artigo 27 da CADH, não são objetos de escusas em nenhuma hipótese: proibição de discriminação fundada em motivos de raça, cor, sexo, idioma, religião ou origem social, negação da suspensão do direito ao reconhecimento da personalidade jurídica; à vida; à integridade pessoal; à proibição da escravidão e servidão; ao princípio da legalidade e da retroatividade; liberdade de consciência e de religião; proteção da família; direito ao nome; direitos da criança; à nacionalidade; direitos políticos, e às garantias indispensáveis para a proteção de tais direitos.

A regra é a não admissão de escusas por parte dos Estados para não realização dos DESCs, como bem já posicionou o Comitê dos Direitos Humanos. E, o Comitê DESCs tem o entendimento de que a progressividade contida no artigo $2^{\circ}(1)$ do PIDESC não se aplica a todos os direitos normatizados no texto, pois há DESCs cuja aplicação é imediata ${ }^{19}$, autoaplicável e não progressiva, portanto, a característica de progressividade não serve para diferenciar as duas pretensas 'categorias' de direitos. Existem direitos civis e políticos que podem apresentar as características de somente ser integralmente garantidos após um longo período de tempo ${ }^{20}$, e, assim, nota-se que direitos de ambas as 'categorias' pode demandar obrigações positivas e negativas, imediatas e progressivas ${ }^{21}$.

Daí a extrema e permanente necessidade da organização social e política estatal de se organizar para implementar as condições e medidas para o exercício dos direitos humanos fundamentais, o que com certeza é atrelado à necessidade de realização de uma vida digna que requer como condição essencial o banimento da extrema pobreza e das discriminações $\operatorname{odiosas}^{22}$.

\footnotetext{
${ }^{19}$ Id., p.62.

${ }^{20}$ Id., p. 64.

21 Terezo afirma que uma das grandes contribuições do Comitê DESCs foi de ter adotado classificação das obrigações do PIDESC como imediatas e progressivas, de consulta e de resultado, de respeito, de proteção, de implementação e de promoção, e que, apesar do artigo 26 da CADH não classificar as obrigações em matéria de DESCs, prevê que os Estados adotem efetivamente todas as medidas necessárias para garantir sua implementação, além do mais, as cláusulas gerais de obrigações e respeito e de garantia constantes nos artigos 1 e 2 da CADH se referem à todos os direitos humanos, não autorizando a pretensão de postergar 'o começo para depois'. Id, p.352.

${ }^{22}$ No julgamento do caso Villagrán Morales (Niños de la Calle) versus Guatemala, de 19/11/1999, a CtIDH adotou o parâmetro do conceito de 'vida digna', como um direito fundamental e pré requisito para que o ser humano possa gozar dos demais direitos humanos, compreendendo não só o sentido de não ser arbitrariamente
} 
A Declaração de Quito dita que o Estado tem a obrigação de não discriminação ${ }^{23}$, de trato igualitário tanto em matéria de direitos civis e políticos como de direitos econômicos, sociais e culturais, e sua obrigação se estende a adoção de medidas especiais, incluindo medidas legislativas e políticas diferenciadas para as mulheres e no resguardo de grupos em situação de vulnerabilidade e de setores historicamente desprotegidos, tais como anciões (as), meninos (as), portadores de deficiência física, enfermos (as) terminais, com problemas médicos persistentes, que padecem de enfermidade mental, vítimas de desastres naturais, que vivem em zonas perigosas, refugiados, comunidades indígenas e os grupos de baixa renda ou em situação de pobreza extrema.

Deveras, as noções de igualdade e de vulnerabilidade caminham juntas no que diz respeito à proteção dos direitos humanos, uma vez que se encontram vulnerabilizados quem apresentam, por diversos motivos, diminuídas suas capacidades de enfrentar as violações de direitos humanos, estando tal diminuição de capacidade e vulnerabilidade associadas às determinadas condições em que está inserido o indivíduo como membro de um grupo específico identificado, regra geral, por estar em condições de clara desigualdade material em relação ao grupo majoritário, que nada tem a ver com minoria ou maioria numérica ${ }^{24}$.

O artigo 26 da CADH norteia um 'começo', usando aqui a expressão tão destacada por Terezo, de forma que os organismos do sistema interamericano deverão tê-lo como base de fundamentação na construção de decisões consonantes e sistematizadas para a proteção e tomada de medidas concretizadoras dos direitos humanos, o que não exclui o uso de outras fontes internacionais, a conferir a efetividade dos $\operatorname{DESCs}^{25}$, e, especialmente, destinar máxima atenção de proteção e garantia desses direitos aos grupos vulneráveis, pois, na grande

privado da vida em si, mas, além, o de que tenha garantido pelo Estado as condições para desfrutar e exercer os seus direitos humanos. Disponível em: http://www.corteidh.or.cr/docs/casos/articulos/Seriec_63_esp.pdf. Acesso em: 07 jul. 2015.

${ }^{23}$ Artigo 29,'a'.

${ }^{24}$ Conceitos extraídos do prólogo da obra da Dhes - Rede de Direitos Humanos e Educação Superior. BELTRÃO, Jane Felipe; BRITO FILHO, José Claudio Monteiro de; GÓMEZ, Itziar; PAJARES, Emilio; PAREDES, Felipe; ZÚÑIGA, Yanira (Coords.). Derechos humanos de los grupos vulnerables, 2014, p.251-284. Disponível em: http://www.upf.edu/dhes-alfa/materiales. Acesso em: 09 mai. 2015, p.13-15. Explica que a vulnerabilidade de gênero é a condição que determina que as mulheres se encontram em situação de especial vulnerabilidade em relação aos direitos humanos, em função do poder que estas têm nas sociedades em que vivem, historicamente reduzidos por concepções androcêntricas. A incapacidade física, sensorial, mental e intelectual, ou simplesmente, as incapacidades diferentes impõem barreiras de acesso ao pleno exercício de alguns dos direitos básicos, vulnerabilizando as pessoas com deficiência em relação aos direitos humanos. Outro exemplo de grupo vulnerabilizado citado é o das minorias étnicas, pois a organização social historicamente segregou tais grupos, violando gravemente seus direitos humanos.

${ }^{25}$ Artigo 29, '1' da Declaração de Quito de 1998: "Se deve garantir a todas as pessoas uma total realização de sua condição de cidadania e, correspondentemente, sua igualdade formal e material para assegurar a plena vigência dos direitos econômicos, sociais e culturais". 
maioria dos casos, tais grupos sofrem violações em seus direitos em decorrência de condutas preconceituosas e discriminatórias que profanam todos os valores éticos, morais e jurídicos do direito internacional dos direitos humanos, e além do que, a violação de um determinado direito sempre é imbricado à violação de outros direitos.

A proteção indireta dos DESCs é tratada na obra de Terezo ${ }^{26}$, citando, como exemplo, que a violação do artigo 24 da $\mathrm{CADH}$, com seu conceito de direito à igual proteção à lei e não discriminação, é a base essencial ao conceito de direitos humanos e à dignidade da pessoa humana, e essa proteção alcançam os direitos patrimoniais e liberdades vulneráveis, protegendo os DESCs das vítimas. Portanto, a interpretação dos DESCs é ampla, verdadeira interpretação do sentido social, econômico e cultural, de forma que as normas da CADH devem ser interpretadas e aplicadas extensivamente aos DESCs na medida e aspectos que resultem razoavelmente exigíveis por si mesmo, e, neste sentido, o sistema interamericano vem buscando proferir decisões que envolvam DESCs, valendo-se dos direitos individuais, os quais estão amplamente protegidos pela $\mathrm{CADH}^{27}$.

Vejamos, abaixo, alguns casos julgados pela CtIDH acerca de graves violações de direitos humanos ocorridas em decorrência dos estados de vulnerabilidade das vítimas, que acarretaram múltiplas violações, inclusive de DESCs.

\section{Caso da Penitenciária Miguel Castro Castro versus Peru. Combate à violência de gênero.}

O caso da Penitenciária Miguel Castro Castro versus Peru, julgado em $2006^{28}$, foi o primeiro em que a CtIDH examinou demanda sobre a questão de gênero, interpretando e aplicando em conjunto as normas gerais da CADH e a normas especiais da Convenção Interamericana para Prevenir, Punir e Erradicar a Violência contra a Mulher, de 1994, bem como aplicou normas da Convenção Interamericana para Prevenir e Punir a Tortura, de 1985.

Verdade que até o dito julgamento, a CtIDH já tinha recebido consultas que versavam sobre litígios onde mulheres se destacavam como protagonistas e temas que protegiam a questão da igualdade de gênero, como a Opinião Consultiva n. $4 / 1984^{29}$, e casos em que as mulheres figuravam como vítimas de violações em seus direitos cujas situações careciam de medidas cautelares, porém, o Caso da Penitenciária Miguel Castro Castro foi o

\footnotetext{
${ }^{26}$ Op.cit., p.258-260.

${ }^{27}$ Id., p. 261.

${ }^{28}$ Disponível em: http://www.corteidh.or.cr/docs/casos/articulos/seriec_160_esp.pdf. Acesso em: 15 jun. 2015.

${ }^{29}$ Ver nota 29 supra, que faz referencia à OC 4/1984.
} 
que pioneiramente firmou considerações vinculadas direta e imediatamente com a especial condição de gênero das vítimas ${ }^{30}$.

Em breve síntese, o caso Penitenciária Miguel Castro Castro remonta à Operação 'Mudança 1', de 1992, na cidade de Lima, com a justificativa de transferir 135 mulheres de uma unidade prisional, sendo que durante a operação, que resultou em verdadeira 'tortura coletiva', 41 mulheres faleceram, e centenas foram feridas e submetidas a tratamento cruel e degradante, tendo o desenrolar do caso apontado que o objetivo da transferência seria eliminar as mulheres consideradas pelo governo de Fujimori como 'terroristas'.

A decisão da CtIDH sobre este caso destacou o impacto diferenciado da situação de violência às vítimas em face do fator gênero e reconheceu que as mulheres foram afetadas por atos de violência de maneira diferente aos atos destinados aos homens. Presidiárias foram impelidas à nudez forçada, inspeção íntima realizada por diversos homens, privação de banho por muitos dias e obrigação de fazer necessidades fisiológicas na presença de agentes do Estado e sob mira de arma de fogo, dentre outras atrocidades acometidas inclusive contra gestantes, conforme as provas carreadas que revelam que a brutalidade de agentes do Estado com os prisioneiros "ultrapassa em muito as asas da imaginação"31.

Então, a CtIDH proferiu decisão diante da perspectiva de discriminação de gênero como fator que intensifica o sofrimento da vítima, merecendo reparações específicas que se coadunem com o impacto diferenciado da violência contra a mulher, na sua condição social de desvantagem em relação ao homem ${ }^{32}$.

Destacam-se os votos fundamentados dos juízes García Ramírez e Cançado Trindade, que elevam de importância a proteção dos direitos humanos da mulher e o combate à violência de gênero.

\footnotetext{
${ }^{30}$ A decisão da CtIDH no Caso Massacre Plan de Sánchez versus Guatemala, de 2004, antecedente ao ora comentado caso, fez alusão à violência sexual sofrida pelas mulheres vítimas, mas não houve o desenvolvimento sobre a questão da violência de gênero. Disponível em: http:/www.corteidh.or.cr/docs/casos/articulos/ seriec_105_esp.pdf. Acesso em: 04 jul. 2015.

${ }^{31}$ Cf. voto fundamentado de Cançado Trindade, p. 222.

${ }^{32}$ Considerou a CtIDH que o Peru violou o direito à vida (art. $4 \mathrm{CADH}$ ) e à integridade pessoal (arts. 5.1, 5.2 $\mathrm{CADH}$ ), todos em relação ao artigo 1.1 da $\mathrm{CADH}$, e, em conexão com os artigos 1 , 6 e 8 da Convenção Interamericana para Prevenir e Punir a Tortura. Violou, também, os direitos as garantias judiciais e a proteção judicial (arts. 8.1 e 25 da CADH), em relação ao artigo 1.1 da mesma, em conexão com os artigos 7.b da Convenção Interamericana para Prevenir, Punir e Erradicar a Violência contra a Mulher; e 1, 6, 8 da Convenção Interamericana para Prevenir e Punir a Tortura, bem como condenou o Estado a adotar uma série de medidas de reparação, como programas educacionais, políticas com orientações para prevenir, erradicar e sancionar a dita violência e garantia de não repetição, custeios de tratamentos e de reabilitação, pagamento por danos morais, materiais, danos físicos e psicológicos, divulgação da sentença, etc.
} 
Ramírez afirma que os direitos da mulher estão amparados no sistema internacional universal, porém, no SIPDH, a Convenção Interamericana para Prevenir, Punir e Erradicar a Violência contra a Mulher constitui a Carta Magna específica para a proteção da mulher, um corpus juris especial em sua substância, com necessidade de afirmar a proteção específica que requer os direitos e liberdades das mulheres como peça fundamental para a construção integral do SIPDH e sua eficácia. Assim, o SIPDH opera a partir de um corpus juris em expansão que se propõe a progressivamente abarcar e ser ampliado na proteção das pessoas por meio de normas protetivas de caráter geral e específicas a determinados grupos humanos para que estes gozem de efetivos direitos e liberdades com o fim de atender ao artigo 29 da CADH (normas de interpretação), acolhendo o critério pro personae ínsito ao direito internacional dos direitos humanos.

Cançado Trindade proferiu seu voto fundamentado com o fito de expor suas reflexões pessoais sobre determinados pontos da sentença, dentre eles a importância da análise de gênero. Ressaltou que, neste caso, percebe-se o acometimento por agentes do Estado de gravíssimas violações de normas do direito internacional humanitário, com agravante de que as vítimas não estavam ali como partes beligerantes, e sim, eram presidiárias privadas de suas liberdades e sob a tutela do Estado. Sequer ocorreu num contexto de guerra ou conflito armado, motim ou rebelião de detentos, o que também não justificaria tais atos, mas a verdade é que ocorreu um "massacre premeditado, planejado e executado por agentes do Estado, da mais alta hierarquia do poder estatal"33.

Apesar do valoroso conteúdo da sentença proferida pela CtIDH no Caso da Penitenciária Miguel Castro Castro, pioneira em combater diretamente os crimes perpetuados contra o gênero feminino, pensa-se que poderia ter sido desenvolvido mais sobre o crime de discriminação de gênero como proibição Jus Cogens, por ter ocorrido abjeta intenção de impor sujeição às mulheres, transgredindo as suas conquistas de direitos humanos, relacionadas à saúde, integridade, sexualidade, reprodução, educação, direito à autonomia econômica, acesso ao emprego e aos salários em igualdade de condições com os homens, vida digna, liberdade de expressão, etc.

Zúñiga Añazco ${ }^{34}$ destaca que o corpus internacional dos direitos das mulheres no sistema universal de proteção dos direitos humanos se estrutura sobre os seguintes

\footnotetext{
${ }^{33}$ Voto fundamentado de Cançado Trindade, p. 225.

${ }^{34}$ ZÚÑIGA AÑAZCO, Yanira. La construcción de la igualdad de género en el ámbito regional americano. In: BELTRÃO Jane Felipe; BRITO FILHO, Jose Claudio Monteiro de; GÓMEZ, Itziar; PAJARES, Emilio;
} 
pressupostos teóricos: a superação da divisão entre os direitos humanos e os direitos das mulheres, posto que os últimos integram os primeiros; a certeza de que os direitos humanos das mulheres podem ser violados de forma diferente aos direitos dos homens, verdadeira violência de gênero feminino; a recepção dos postulados do jusfeminismo, que rejeita uma formação neutra de normas de direitos humanos, facilitando a inserção de estereótipos de gênero com concepção androcêntrica; a necessária compreensão do complexo fenômeno da discriminação das mulheres que permeia nas searas do público e privado; e a compreensão de que os Estados podem violar os direitos das mulheres por omissão e por ação, e que deve atenção às questões sobre transversalização da perspectiva de gênero.

Os textos da Convenção Interamericana para Prevenir, Punir e Erradicar a Violência contra a Mulher, de 1994, e da Convenção para a Eliminação de Todas as Formas de Discriminação contra as Mulheres, de 1999, trazem o sentido de que a discriminação é toda a distinção, exclusão ou restrição com base no sexo que tenha por objetivo ou resultado prejudicar ou anular o reconhecimento, gozo ou exercício pela mulher, com base na igualdade do homem e da mulher, dos direitos humanos e das liberdades fundamentais nos diversos campos como o político, econômico, social, cultural e civil, e a violência contra a mulher deve ser entendida como qualquer ação ou conduta, baseada no gênero, que cause morte, dano ou sofrimento físico, sexual ou psicológico à mulher, tanto no âmbito público como no privado.

O SIPDH tem contribuído para que os países incluam em sua agenda política os necessários debates acerca de questões de DESCs de grupos vulneráveis, almejando que tenhamos sólidas bases institucionais para a construção de uma esfera pública transnacional para se erradicar práticas que (infelizmente, ainda) revelam os odiosos contextos sociais e históricos de dominação, subordinação e discriminação de gênero feminino.

Terezo cita que a CIDH vem observando modificações internas com legislações, políticas e programas especializados nas Américas, porém, os indicadores atuais demonstram que a eficácia de tais medidas está muito aquém do necessário ${ }^{35}$.

Deveras, urge que os Estados revisem os conceitos e parâmetros e adotem estratégias nos programas de todos os setores, públicos e privados, com a adequada e sensível proteção e atendimento às questões particulares do gênero feminino, valorando e enfatizando o conteúdo de normas Jus Cogens dos direitos das mulheres, qual seja, o de máximo respeito às suas

PAREDES, Felipe; ZÚÑIGA, Yanira (Coords.). Derechos humanos de los grupos vulnerables, 2014, p. p.187. Disponível em: http://www.upf.edu/dhes-alfa/materiales/. Acesso em: 13 mai. 2015.

${ }^{35}$ Op.cit., p. 317-318. 
particularidades e promoção de participação de ambos os sexos em todas as esferas da vida pública e privada, com o engrandecimento das diferenças e os diversos papéis a serem desempenhados na construção de uma sociedade democrática e justa, bem longe de concepções separatistas.

Vale citar, a título de informação, outro importante caso julgado pela CtIDH que teve como objeto a violência de gênero, que é o Caso González e outras (Campo algodoeiro) versus México $^{36}$, e, ainda, o célebre Caso Maria da Penha Fernandes versus Brasil ${ }^{37}$, que foi o pioneiro na Comissão Interamericana de Direitos Humanos (CIDH) em relação à violência doméstica e familiar, onde, a partir das recomendações do Relatório n. 54/2001 da CIDH, foi sancionada no Brasil a Lei n. 11.340/2006 (Lei Maria da Penha), verdadeiro fruto do processo de reconhecimento dos direitos fundamentais das mulheres, representando um notório avanço na proteção da mulher vítima de violência familiar e doméstica, incluindo, também, uma inovação legal quanto às formas de gênero já positivadas.

O Caso 'Maria da Penha' teve notórios efeitos sociais, culturais e jurídicos na sociedade brasileira e são justamente esses os efeitos que se desejam em todos os países signatários do sistema interamericano (e no âmbito universal, também), pois o combate contra a violência de gênero envolve comprometimento com o valoroso conteúdo material de direitos humanos - Jus Cogens, e representa a evolução do sistema internacional ao reconhecê-los como um dos mais caros valores intrínsecos à dignidade do ser humano.

\section{Caso Ximenes Lopes versus Brasil. Combate às discriminações aos seres humanos com deficiência.}

O caso Ximenes e Lopes levou o Brasil à sua primeira condenação pela CtIDH, em $2006^{38}$. Em breve síntese, Damião Ximenes possuía deficiência mental e idade de 30 anos quando foi internado em uma clínica psiquiátrica vinculada ao Sistema Único de Saúde, por apresentar intenso quadro de sofrimento mental, vindo a falecer com sinais de graves maus tratos e tortura num ambiente de hospitalização degradante (tanto em seu aspecto físico

\footnotetext{
${ }^{36}$ Caso González e outras ('Campo algodoeiro') versus México, julgado pela CtIDH em 2009, refere-se à denúncia pelas mortes de três jovens mulheres, com características de mutilação de seios e genitálias, tortura e violência sexual, enfatizando a violência de gênero, que já era constante naquela sociedade, sem interesse e eficaz investigação pelo Estado, evidenciado o descaso na investigação dos crimes em razão de percepções discriminatórias contra as vítimas, e refletindo reprováveis padrões machistas dos agentes de Estado contra os estereótipos das mesmas. Disponível em: http://www.corteidh.or.cr/docs/casos/articulos/seriec_205_por.pdf. Acesso em: 06 jul. 2015.

${ }^{37}$ Disponível em: http://www.cidh.org/annualrep/2000port/12051.htm. Acesso em: 26 jun. 2015.

${ }^{38}$ Disponível em: http://www.corteidh.or.cr/docs/casos/artículos /seriec_149_por.pdf. Acesso em: 09 mai. 2015.
} 
quanto na conduta de seus profissionais que cuidavam do paciente). A família recorreu à jurisdição brasileira, mas, diante do flagrante descaso do Estado em promover a reparação judicial, socorreu-se no SIPDH.

Destaca-se o assombroso relato da mãe de Damião à $\mathrm{CIDH}^{39}$, e, diante das demais provas carreadas, constatou-se a prática de crimes de torturas com a agravante de ser cometido contra pessoa com deficiência mental. Na realidade, a morte de Damião se insere na cultura de desleixo, segregação, violência e mortificação destinada às pessoas com doenças mentais. O modelo manicomial é prática que está associada aos fatores sociais, culturais e econômicos da coletividade que erroneamente enxerga a deficiência como algo negativo. Tal modelo mata, escraviza e inviabiliza qualquer tipo de reabilitação e vida digna ao portador de deficiência mental e é violador de múltiplos direitos humanos consagrados na CADH.

A CtIDH declarou que o Brasil violou as disposições da CADH em seus artigos 4.1 (direito à vida), 5.1 e 5.2 (direito à integridade pessoal), e artigos 8.1 e 25.1 (direitos às garantias e à proteção judicial), todos em relação à obrigação geral de respeitar e garantir direitos (1.1), bem como o condenou a garantir em prazo razoável uma série de medidas, entre as quais, desenvolver um programa de formação e capacitação para o pessoal médico, de psiquiatria e de psicologia, de enfermagem e auxiliares de enfermagem e para todas as pessoas vinculadas ao atendimento de saúde mental, em especial sobre os princípios que devem reger o trato das pessoas portadoras de deficiência mental, conforme os padrões internacionais sobre a matéria e o que foi disposto na sentença.

A supervisão do SIPDH ainda não considerou integralmente cumprida pelo Brasil todos os termos da referida sentença ${ }^{40}$, mas houve significativos avanços com a 'Política Nacional de Saúde Mental', objeto de uma nova perspectiva do país em relação às pessoas

\footnotetext{
${ }^{39}$ Relatou a sra. Albertina Viana Lopes que quatro dias após a internação de seu filho, foi à clínica e teve sua entrada negada, e que, forçando a entrada e chamando por Damião, o encontrou vindo em sua direção, caindo à seus pés, com as mãos amarradas para trás, apresentando sangramento pelo nariz, cabeça inchada "que nem parecia ele" e olhos quase fechados. Estava imundo, machucado, com esquimoses roxas e com cheiro de excrementos, e falou: "polícia, polícia, polícia". Sua mãe, então, imediatamente pediu socorro aos profissionais, e deixando a clínica consternada, logo após veio a ser comunicada da morte de seu filho. Consta no relatório da CIDH o intenso sofrimento acarretado a toda família (pai, irmão gêmeo, irmã e mãe, esta tendo desenvolvido depressão, desejo de morte e profundo desespero em não machucar a vida de plantas, insetos e animais). COMISIÓN INTERAMERICANA DE DERECHOS HUMANOS. 2004. Demanda en el Caso Damião Ximenes Lopes (Caso 12.237) contra la República Federativa del Brasil, p. 21. Disponível em: http://www.corteidh.or.cr/ docs/casos/ximenes/dcidh.pdf. Acesso em: 05 jun. 2015.

${ }^{40}$ Cf. RESOLUCIÓN DE LA CORTE INTERAMERICANA DE DERECHOS HUMANOS DE 17 DE MAYO DE 2010 CASO XIMENES LOPES VS. BRASIL. SUPERVISIÓN DE CUMPLIMIENTO DE SENTENCIA. Disponível em: http://www.corteidh.or.cr/docs/supervisiones/ximenes_17_05_10.pdf. Acesso em: 12/07/2015. Ver casos de etapa em supervisão pela CtIDH, disponível em: http://www.corteidh.or.cr/index.php/casos-enetapa-de-supervision. Acesso em: 12 jul. 2015.
} 
com transtornos mentais, com edição de normas de proteção e regulamentadoras de medidas, entre as quais se destacam a Lei $n^{0} 10.216$, de 06/04/2001 (que dispõe sobre a proteção e os direitos das pessoas com transtornos mentais e redireciona o modelo assistencial em saúde mental) e a Lei n. 10.708, de 31/07/2003 (que institui o auxílio de reabilitação psicossocial para pacientes com transtornos mentais egressos de internações) ${ }^{41}$.

Mas, ainda vivemos na realidade de constantes denúncias acerca de maus tratos às pessoas com deficiência mental, e a maioria dos casos, infelizmente, nem chegam ao conhecimento das autoridades ou da sociedade, uma vez não raro se tratam de crimes cometidos por profissionais de saúde ou familiares acobertados pela privacidade do internamento da pessoa deficiente ou de seu próprio lar.

A Convenção Interamericana para a Eliminação de todas as Formas de Discriminação contra as Pessoas Portadoras de Deficiência foi assinada em 1999, e a Convenção Internacional sobre os Direitos das Pessoas com Deficiência e seu protocolo Facultativo, em 2007 ${ }^{42}$. A Convenção sobre os Direitos das Pessoas com Deficiência descreve que as pessoas com deficiência são aquelas que têm impedimentos de longo prazo de natureza física, mental, intelectual ou sensorial, podendo a deficiência dessas pessoas acarretar a obstrução da participação plena e efetiva na sociedade em igualdades de condições com as demais pessoas, termo mais específico e adequado para distinguir do conceito geral de 'pessoas com necessidades especiais" ${ }^{43}$.

\footnotetext{
${ }^{41}$ Vale frisar a importância do 'Movimento da Luta Antimanicomial', com início em 1987, pugnando pela 'reforma psiquiátrica' com tratamento de qualidade na área da saúde pública voltada para o problema do trato com a saúde mental. Sobre os progressos acerca do assunto, ver: Avanços das Políticas Públicas para as Pessoas com Deficiência. Uma análise a partir das Conferências Nacionais. PRESIDÊNCIA DA REPÚBLICA. Secretaria Nacional de Promoção dos Direitos da Pessoa com Deficiência. Secretaria de Direitos Humanos da Presidência da República. Brasília, 2012. Disponível em: http://www.pessoacomdeficiencia. gov.br/app/sites /default/files/publicacoes/livro-avancos-politicas-publicas-pcd.pdf. Acesso em: 11 jul. 2015.

${ }^{42}$ Destacamos outras fontes normativas de garantia de proteção aos deficientes: Declaração de Sundeberg, Torremolinos, Espanha, de 1981 (trata do acesso à educação, ao treinamento, à cultura e à informação); Declaração de Cave Hill, Barbados, de 1983 (considerado um dos principais documentos a condenar a imagem de pessoas com deficiência como cidadãos de segunda categoria); Declaração de Jomtien, Tailândia, de 1990; Declaração de Santiago, de 1998 (trata do combate à discriminação e da integração de grupos vulneráveis à vida política e econômica); Declaração de Salamanca, de 1994; Declaração de Quito, de 1998 (trata da exigibilidade e realização dos DESC na América Latina); Declaração de Caracas, de 2002; Declaração de Sapporo, Japão, de 2002 (trata da acessibilidade, da inclusão, da genética e bioética, da educação inclusiva e da vida independente); Declaração de Madri, de 2002; World Report on Disabilit (Informe Mundial la Discapacidad), de 2011; e outros diversos documentos internacionais, como a Declaração Universal dos Direitos Humanos, de 1948.

43 "São pessoas com necessidades especiais todas aquelas que, em dado momento, de forma permanente ou temporária, às vezes somente pela falta de mínimos recursos financeiros para correções, têm dificuldades ou restrições de acesso a determinados bens, direitos, oportunidades elou espaços", ou seja, o gênero acolhe as pessoas com deficiência, idosos, gestantes, e qualquer pessoa em situação que careça de um tratamento diferenciado devido à sua necessidade especial." BRITO FILHO, op.cit., p.76.
} 
Brito Filho, tratando sobre pessoas com deficiência, afirma que dificilmente identificaremos, ao longo da história, integrantes de grupos vulneráveis mais discriminados. Alerta que, se já se foi o período em que essas pessoas eram eliminadas por terem alguma deficiência, ainda hoje estas sofrem com uma convivência em sociedade bastante complicada, com práticas e convicções de segregação para todos os atos da vida ${ }^{44}$.

Enfatiza o autor que o combate às práticas discriminatórias e a possibilidade de acesso das pessoas com deficiência a todos os espaços da sociedade se faz possível pela adoção de dois modelos. No primeiro, o Estado cuida de editar normas que vedem as práticas discriminatórias e criminaliza tais atos, impondo, também, sanções de natureza administrativa, civil e trabalhista. Que, embora esse modelo repressor seja eficaz em reprimir a conduta discriminatória, não gera muito efeito em incluírem as pessoas com deficiência na ampla e efetiva participação da vida em sociedade, o que será realizado pelo segundo modelo, o das ações afirmativas, verdadeiro modelo de combate à discriminação de forma a garantir o acesso aos recursos valiosos, com edição de normas que estabelecem critérios diferenciados de acesso a determinados bens, proporcionando uma igualdade real às pessoas ${ }^{45}$, ressaltando que é preciso que as pessoas com deficiência tenham acesso aos diversos espaços onde poderão usar os recursos à sua disposição ${ }^{46}$.

Destaca Hawking que o Relatório Mundial sobre a Deficiência (ou Informe Mundial La Discapacidad ou World Report on Disabilit) ${ }^{47}$ formulam recomendações para a adoção de medidas em escala local, nacional e internacional, sendo uma poderosa e inestimável ferramenta para todas as instâncias normativas, aos praticantes e defensores dos direitos humanos das pessoas com deficiência. Almeja o astrofísico que a partir da Convenção sobre os Direitos das Pessoas com Deficiência e a publicação do Relatório Mundial sobre a Deficiência consigamos a efetivação da inclusão das pessoas com deficiência.

Deveras, deficiência nefasta é a que míngua o ser humano em sua capacidade de querer a efetivação de uma vida digna às pessoas com deficiência. E o conceito de vida digna

\footnotetext{
${ }^{44}$ Op.cit., p.73.

${ }^{45}$ Op.cit., p. 81-82.

${ }^{46}$ Op.cit., p.84.

47 INFORME MUNDIAL LA DISCAPACIDAD. Organización Mundial de la Salud, 2011. Destaque para o prólogo do professor e astrofísico Stephen W Hawking. Disponível em: http://www.who.int/disabilities/world_report/2011/accessible_es.pdf. Acesso em: 05 jul. 2015. RELATÓRIO MUNDIAL SOBRE A DEFICIÊNCIA. Governo de São Paulo. Secretaria dos Direitos da Pessoa com Deficiência. Disponível em: http://www.Pessoacomdeficiencia.sp.gov.br/usr/share/documents/ RELATORIO_ MUNDIAL_COMPLETO.pdf. Acesso em: 05 jul. 2015.
} 
a essas pessoas se estende, necessariamente, à ampla capacidade das mesmas exercerem com autonomia seus talentos e suas aptidões em todas as searas, em participar da vida em sociedade e terem investimentos em recursos para obter acesso aos diversos espaços onde poderão usar tais recursos, e autonomia para poder liberar os seus vastos potenciais em todas as áreas que desejarem. E são esses conceitos que norteiam as normas Jus Cogens de proteção às pessoas com deficiência.

Os Estados têm a obrigação moral, ética e jurídica de erradicar todas as barreiras das pessoas deficientes e, os organismos internacionais, de promover e sistematizar tais normas protetivas e garantidoras aos portadores de deficiência como sendo cogentes, imperativas, inderrogáveis, normas de direitos humanos Jus Cogens.

A propósito, na sentença do Caso Ximenes Lopes, Cançado Trindade proferiu brilhante voto separado. Entre as considerações feitas, está a da necessidade de ampliação do conteúdo material do Jus Cogens, além da fixação da proibição da tortura ou tratamentos cruéis, desumanos e degradantes, uma vez que o fato da vítima direta do caso ser pessoa com deficiência mental, e de ser, inclusive, o primeiro caso do gênero perante a CtIDH, revela-o de circunstância agravante, relacionada à situação de alta vulnerabilidade da vítima, e que reveste-se de caráter erga omnes, abarcando também as relações interindividuais.

Relatou Cançado os seus diversos votos proferidos no sentido de expor as obrigações dos Estados que se revestem de caráter erga omnes, abordando a necessidade de a Corte ter se esmerado mais na fundamentação de seus próprios obiter dicta, de ter dedicado mais tempo à fundamentação da proibição de Jus Cogens, já que as pessoas portadoras de deficiências (mais de 600 milhões de pessoas, ou seja, aproximadamente $10 \%$ da população mundial, cita ele) integram estes segmentos mais vulnerabilizados da população, assumindo transcendental importância o princípio básico da igualdade e da não-discriminação.

A questão dos direitos humanos das pessoas com deficiência, e especialmente aqui se enfatizam os DESCs, é uma questão de normas Jus Cogens. Para as pessoas com deficiência exercerem livre e amplamente seus direitos e terem acesso aos bens valiosos de uma vida digna e independente, com autonomia na produção laborativa, realização pessoal e familiar, acesso à saúde, educação, esportes, transportes e a toda a tecnologia disponível, inclusive genética e bioética, faz-se imperiosa a tomada de medidas em todos os setores da sociedade para que sejam tais direitos e acessos realizados em condições de igualdade, na perfeita compreensão do significado deste magno princípio. 


\section{Caso do Povo indígena Kichwa de Sarayaku versus Equador. Direitos e garantias aos povos indígenas.}

O caso se refere à outorga, na década de 90, pelo Estado do Equador, de permissão a uma empresa privada petroleira para realizar atividades de exploração de petróleo no território do Povo Sarayaku. Este Povo subsiste da agricultura familiar coletiva, da caça, da pesca e da coleta, e se encontram em um dos assentamentos 'Kichwa' da Amazônia, de grande concentração populacional (compreendendo por volta de 1.200 habitantes) e grande extensão de território que oferecem uma das maiores biodiversidade no mundo ${ }^{48}$.

A CtIDH julgou o caso em 2012, considerando o Equador responsável pela violação dos direitos à consulta, à propriedade comunal indígena e à identidade cultural (art. 21, e em relação com os arts. 1.1 e 2, todos da $\mathrm{CADH}$ ); por haver colocado gravemente em risco os direitos à vida e à integridade pessoal (arts. 4.1 e 5.1 da CADH), em relação com a obrigação de garantir o direito à propriedade comunal (arts. 1.1 e 21 da $\mathrm{CADH}$; pela violação dos direitos às garantias judiciais e à proteção judicial (arts. 8.1 e 25, e em relação com o art. 1.1, todos da $\mathrm{CADH})$.

Por ser um caso com múltiplos aspectos, conceitos e conteúdos em relação às várias violações de direitos humanos de povo indígena, nos concentraremos na violação do artigo 21 da $\mathrm{CADH}$, ou seja, do direito à propriedade privada. Temos, então, a particularidade de que o respeito a tal dispositivo em relação ao povo indígena obriga inexoravelmente ao respeito aos direitos à consulta, à propriedade comunal indígena e à sua identidade cultural.

A CtIDH declarou que o Equador não respeitou os direitos à consulta e seu caráter prévio como forma essencial de proteção à propriedade comunal indígena, na conformidade com o artigo 15.2 da Convenção 169 da Organização Internacional do Trabalho (OIT) ${ }^{49}$. A consulta deveria ter sido realizada antes de o Estado empreender ou autorizar qualquer programa de prospecção e exploração dos recursos existentes em terras indígenas, bem como a realizar na boa fé e com a finalidade de ser um instrumento de participação e consenso sobre as medidas, mediante procedimentos apropriados a permitir que os povos compreendam e se façam compreender, tanto em relação às medidas e acordos tomados, quanto aos seus direitos estabelecidos na Declaração das Nações Unidas sobre Direitos dos Povos Indígenas, de 2007.

\footnotetext{
${ }^{48}$ Disponível em: corteidh.or.cr/docs/casos/articulos/seriec_245_por.doc. Acesso em: 13 jun. 2015.

${ }^{49}$ Disponível em: http://www.planalto.gov.br/ccivil_03/_ato2004-2006/2004/decreto/d5051.htm. Acesso em: 13 jun. 2015.
} 
De acordo com as normas da Convenção 169 da OIT (7.3), os estudos de impacto ambiental devem ser realizados pelos governos em cooperação com os povos interessados, com análise dos resultados que fornecerão critérios fundamentais para sua execução, avaliando a incidência social, espiritual e cultural e sobre o meio-ambiente das atividades previstas. Deve o Estado compreender o sentido da 'cosmovisão' a ser destinada à propriedade comunal indígena, pois esta porta elementos da natureza e da selva imbricados com o conceito de vida que interage com os habitantes e com a coexistência de seres espirituais, inclusive havendo determinados espaços sagrados que são acessados somente pelos considerados 'sábios'.

O desrespeito ao direito de propriedade das comunidades indígenas também afetou o direito à identidade cultural do Povo de Sarayaku, na medida em que, com base no princípio da não discriminação, o direito à identidade cultural é 'ingrediente e via de interpretação transversal' para a garantia dos direitos dos povos indígenas, reconhecendo a $\mathrm{CtIDH}^{50}$ a estreita vinculação do território com as tradições, costumes, línguas, artes, rituais, conhecimentos e outros aspectos da identidade dos povos indígenas, sendo esse patrimônio cultural imaterial transmitido pelas gerações, e com valores trazidos por seus ancestrais, que integram a identidade cultural dos povos indígenas ${ }^{51}$.

Burger cita que a Declaração Universal dos Direitos dos Povos Indígenas é o marco de reconhecimento universal de tais direitos por parte da organização internacional universal, sendo complementada com a Convenção 169/1989 da OIT sobre Povos Indígenas e Tribais, e com os principais mecanismos internacionais de direitos humanos dedicados à proteção dos povos indígenas, a saber, o Relator Especial sobre os direitos dos povos indígenas e o Mecanismo de Peritos sobre os direitos dos povos indígenas, estabelecidos no Conselho de

\footnotetext{
${ }^{50}$ O caso da Comunidade Mayagna (Sumo) Awas Tingni versus Nicarágua, julgado em 2000, foi o primeiro a ser levado à CtIDH. Com base no artigo $21 \mathrm{da} \mathrm{CADH}$, a Corte reconheceu o caráter coletivo do direito à terra dos índios do povo Awas Tingni, bem como a imbricada relação entre a terra, a cultura e a espiritualidade daquele povo, afirmando que os povos indígenas têm o direito coletivo à propriedade das terras que tradicionalmente usam e ocupam, independentemente do reconhecimento através de títulos do governo sobre tais terra, pois esse direito à propriedade se fundamenta no direito costumeiro dos povos. Disponível em: http://www.corteidh.or.cr/docs/ casos/articulos/seriec_79_ing.pdf. Acesso em: 12 jul. 2015.

${ }^{51}$ Principais precedentes citados pela CtIDH no julgamento do Povo Indígena Kichwa de Sarayaku: Comunidade Moiwana versus Suriname, de 2005; Comunidade Indígena Yakye Axa versus Paraguai, de 2005; Comunidade Indígena Sawhoyamaxa versus Paraguai, de 2006; Povo Saramaka versus Suriname, de 2007; Comunidade Indígena Xákmok Kásek versus Paraguai, de 2010.
} 
Direitos Humanos e no Foro Permanente para as questões indígenas, que prestam assessoramento ao Conselho Econômico e Social das Nações Unidas ${ }^{52}$.

Estupiñan Silva e Ibáñez Rivas afirmam que a CADH deve ser aplicada de forma harmoniosa nos ordenamentos internos e com obrigações diferenciadas em matéria de proteção dos direitos humanos dos povos indígenas e tribais, a incluir os conteúdos culturais inerentes a esses povos ${ }^{53}$. De acordo com a compreensão do texto das autoras, tem o sistema interamericano enriquecido o conteúdo dos direitos humanos dos povos indígenas e tribais, com ampliação das fronteiras da $\mathrm{CADH}$, possibilitando a abertura para visibilidade e aplicação de direitos e garantias em construção, obedecendo aos particularismos dos povos indígenas, sem que com isso se cogite de perder a harmonia do sistema. Pensamos que, procedendo dessa forma, tal sistema se revela fortalecido em sua legitimidade, atendendo às particularidades do continente americano e facilitando a convergência a um pluralismo de normas jurídicas identificadas com as sociedades democráticas e multiculturais deste continente.

As autoras destacam importantes julgamentos realizados pela $\mathrm{CtIDH}$, trazendo definição de conteúdo e alcance dos direitos dos povos indígenas firmados nas decisões, e, aqui, destacamos dois direitos que consideramos ser Jus Cogens (o que não exclui outros de serem assim considerados): 1- o direito à vida dos indígenas porta um conceito ampliado para uma 'vida digna', atenta as suas particularidades, com direito à saúde, à alimentação, à água limpa, à moradia e serviços sanitários, à educação e à identidade cultural; 2- o direito à propriedade, onde se destaca o direito dos povos indígenas sobre as suas terras, os territórios de seus ancestrais, os aspectos culturais e das crenças de sua comunidade ${ }^{54}$.

Nesse contexto, a interpretação do direito de propriedade de povo indígena passa necessariamente pela 'cosmovisão' a revelar os valores materiais e imateriais que lhe são inerentes, carregando a 'terra' os elementos incorpóreos, infungíveis e longe de um conceito de riqueza econômica. O direito coletivo à propriedade dos povos indígenas trazem os

\footnotetext{
52 BURGER, Julian. "La protección de los pueblos indígenas en el sistema internacional” In: BELTRÃO, Jane Felipe; BRITO FILHO, José Claudio Monteiro de; GÓMEZ, Itziar; PAJARES, Emilio; PAREDES, Felipe; ZÚÑIGA, Yanira (Coords.). Derechos humanos de los grupos vulnerables, 2014, p.220-250. Disponível em: http://www.upf.edu/dhes-alfa/materiales/. Acesso em: 12 mai. 2015.

53 ESTUPIÑAN SILVA, Rosmerlin; IBÁÑEZ RIVAS, Juana María. "La jurisprudencia de la Corte Interamericana de Derechos Humanos en materia de pueblos indígenas y tribales”. In: BELTRÃO Jane Felipe; BRITO FILHO, Jose Claudio Monteiro de; GÓMEZ, Itziar; PAJARES, Emilio; PAREDES, Felipe; ZÚÑIGA, Yanira (Coords.). Derechos humanos de los grupos vulnerables, 2014, p.301-337. Disponível em: http://www.upf.edu/dhes-alfa/materiales/. Acesso em: 13 mai. 2015.

${ }^{54}$ Destacam as autoras o conteúdo e alcance de diversos direitos. Op.cit., p.318-324.
} 
elementos da terra, da cultura e da espiritualidade, e em decorrência dessa especial particularidade e vulnerabilidade em seus direitos humanos, são normas Jus Cogens, a proteger outros múltiplos direitos humanos desses povos, inclusive a sua identificação cultural essencial para a sua dignidade e existência.

\section{Considerações finais.}

O agente de Estado que abusa do poder público para cometer violação de direitos humanos é o mais perigoso dos criminosos, sendo as normas Jus Cogens uma poderosa arma contra esse potencial violador.

Com pretensão de universalidade e obrigações internacionais cogentes, irrevogáveis e efeitos erga omnes, o Jus Cogens assume a função de impedir que um Estado limite a abrangência e alcance da tipificação de determinada violação contra direitos humanos para se isentar de responsabilidade internacional.

As normas Jus Cogens não visam uma imposição de hegemonia de cultura, na medida em que devem ser compreendidas como uma universalidade de direitos humanos atenciosa às peculiaridades e às diversas formas de concretização desses direitos. Assim, o Jus Cogens se constitui em garantia de proteção internacional contra a pretensão de qualquer Estado em acometer graves violações aos grupos vulneráveis, garantindo o exercício das particularidades culturais.

O sentido e alcance das normas Jus Cogens devem ser construídos de forma adequada e conforme as diversidades de cada grupo social, com interpretação e aplicação compatível à ratio e fundamentação da norma protetora de direitos humanos. Não fosse assim, não seriam normas universais, posto que a universalidade visa abranger 'a todos' e só é possível alcançar 'a todos' com o respeito às importantes particularidades existentes nos grupos, daí a importância de se trazer conceitos de Donnelly sobre a universalidade (relativa) dos direitos humanos que é, inclusive, compatível com as citadas diretrizes do Programa de Ação da II Conferência Mundial de Direitos Humanos (Viena, 1993).

A ajustada perspectiva da universalidade (relativa) dos direitos humanos é que vai possibilitar que a norma Jus Cogens seja adaptada às diversidades culturais em cada caso concreto, e aqui não há de se cogitar numa 'mitigação' do conceito da norma superior, mas sim, verdadeira adaptação/construção diante das particularidades do ser humano, de forma a atender o valor máximo da dignidade da pessoa humana e os fundamentos que permeiam o Direito Internacional dos Direitos Humanos, que carrega em seu âmago o respeito à 
identidade cultural de cada pessoa ou grupo social, posto que não se realiza a dignidade da pessoa humana afastando-a de seu grupo social, de seus valores culturais, de sua identidade.

A consciência universal para a construção do 'Novo Jus Gentium do Século XXI' perquirida nos votos de Cançado Trindade não visa que as sociedades percam sua identidade cultural em busca de uma hegemonia de modelo de sociedade, ao contrário, visa proteger o valor e garantir tais identidades, buscando oferecer condições para que cada grupo social exerça de forma digna suas particularidades.

A presença de normas Jus Cogens num processo de interpretação judicial não veda a perspectiva de construção com base nessas normas de núcleo duro, ao contrário, é assim que será extraído e realizado o sentido da norma de direitos humanos de acordo com o caso concreto e sempre a atender, ao máximo possível, o princípio fundamental da dignidade da pessoa humana. Em um processo de interpretação ou diálogo judicial, o valor persuasivo aumenta consideravelmente quando estão presentes normas Jus Cogens, mas não necessitam serem modelos de convergência absoluta. A autoridade judicial pode/deve construir excelentes medidas protetivas e de aplicabilidade acerca desses direitos humanos diferenciados pela qualidade de sua natureza substancial.

É claro que na perspectiva de um sistema regional, como o sistema interamericano de proteção de direitos humanos, os modelos de convergência tendem a ser tornar mais constantes e evidentes, e a jurisprudência sistematizada da CtIDH tem o papel de destaque para a construção dos parâmetros de implementação para a proteção, garantia e efetividade dos mais caros direitos humanos, especialmente os destinados aos grupos vulneráveis.

Afasta-se qualquer posição excessivamente normativista/formalista e visa-se direitos humanos aptos a abarcar os particulares valores e necessidades dos grupos vulneráveis, com a implementação de espaços sociais democráticos a permitir a progressiva efetivação dos DESCs desses grupos, e que sejam reconhecidos como normas Jus Cogens em razão da extrema relevância de determinados direitos ali inseridos, pois, não raro, a violação de um desses direitos acarreta graves e multíplices violações a outros, inclusive impedindo a convivência da pessoa ou do grupo violado em seu meio social e do exercício de outros direitos intrínsecos à sua dignidade humana e à sua coletividade, a exemplo da citada demarcação pelo Estado de terras indígenas, onde o conceito de propriedade não pode ser o fator determinante para decisões e medidas do Estado, já que, para os indígenas, a 'terra' abarca um conceito orientado por uma 'cosmovisão', com um conjunto de valores materiais e imateriais a serem respeitados, garantidos e valorados pelo Estado. 
Em algumas situações, temos que determinado direito de um grupo vulnerável apresenta diferenciada relevância em seu valor, acarretando que esse direito seja identificado como norma Jus Cogens para proteção específica dos direitos humanos desse grupo. Têm os órgãos judiciais e administrativos o dever de reconhecer a superior qualidade material desses direitos humanos, evidenciando que a universalidade do Jus Cogens serve para proteger e garantir as relevantes particularidades e especificidades dos grupos vulneráveis.

As discriminações odiosas ligadas às questões de gênero, de raça, de preconceito aos grupos étnicos e portadores de deficiência, são, indubitavelmente, violações de normas Jus Cogens, na mais ampla concepção defendida por Cançado Trindade, acarretando aos Estados o dever de respeitar, proteger, garantir o exercício de todos os direitos para que não sofram nenhuma discriminação, e adotar medidas para erradicá-la, sob pena da pessoa que sofreu a discriminação ser impedida de exercer vários de seus direitos humanos em razão da discriminação ocorrida, seja de forma ativa ou velada, talvez esta a forma mais perigosa de seu exercício.

As discriminações ligadas aos grupos vulneráveis acometem de forma intolerável padrões de ética e de moral internacionais e padrões jurídicos, atentando contra os mais caros valores que organizam a sociedade humana e os fundamentos do Direito Internacional dos Direitos Humanos. A transgressão e o desrespeito aos DESCs de grupos vulneráveis são, em quase todos os casos, relacionados às discriminações e preconceitos do Estado para com esses grupos, verdadeira resistência de implementação do conceito de uma sociedade justa e igual, com inclusão de todos e plena efetividade dos direitos e garantias internacionalmente reconhecidos.

Por isso, determinados DESCs de grupos vulneráveis assumem a condição de Jus Cogens, pois suas violações ultrapassam a condição de uma violação de direito humano, são violações dos mais preciosos valores e padrões da humanidade, e cabe ao juiz verificar, com muita atenção e sensibilidade, não se frutando de se socorrer aos conhecimentos científicos da antropologia ou etnografia ou outros especialistas, de acordo com a necessidade de cada caso, para detectar a ocorrência dessas graves e particulares formas de violação de direitos humanos.

Não bastante, faz imperioso que os organismos internacionais, tribunais e administração pública dos Estados promovam diálogos transnacionais para sistematizarem decisões convergentes acerca da importância da elevação de DESCs dos grupos vulneráveis 
como normas Jus Cogens, cabendo aos Estados, progressivamente, efetivarem as medidas necessárias para a garantia do exercício de tais direitos.

Os Jus Cogens devem ser progressivamente construídos e sistematizados, a cada caso concreto, pelos organismos internacionais e órgãos judiciais e administrativos dos Estados, posto que essas normas têm capacidade de ampliação em sua dimensão substancial e adaptação às diversas particularidades das sociedades e grupos sociais, e sua ratio é justamente garantir aos seres humanos a não ocorrência de atos decorrentes de discriminações odiosas e protegê-los de qualquer ato do poder estatal com tendência à pretensão de supremacia sobre quem se encontrar em estado de vulnerabilidade de direitos humanos.

\section{Referências}

BELTRÃO, Jane Felipe; BRITO FILHO, José Claudio Monteiro de; GÓMEZ, Itziar; PAJARES, Emilio; PAREDES, Felipe; ZÚÑIGA, Yanira (Coords.). Derechos humanos de los grupos vulnerables, 2014, p.251-284. Disponível em: http://www.upf.edu/dhes-alfa/materiales. Acesso em: $09 / 05 / 2015$.

BRITO FILHO, Claudio Monteiro de. Assegurando o gozo dos direitos em condições de igualdade: direitos humanos das pessoas com deficiência. In: BELTRÃO, Jane Felipe; BRITO FILHO, José Cláudio Monteiro de; GÓMEZ, Itziar; PAJARES, Emilio; PAREDES, Felipe; ZÚÑIGA, Yanira (Coords.). Derechos humanos de los grupos vulnerables, 2014, p.73-87. Disponível em: http://www.upf.edu/dhes-alfa/materiales. Acesso em: 09/05/2015

BURGER, Julian. La protección de los pueblos indígenas en el sistema internacional. In: BELTRÃO, Jane Felipe; BRITO FILHO, José Cláudio Monteiro de; GÓMEZ, Itziar; PAJARES, Emílio; PAREDES, Felipe; ZÚÑIGA, Yanira (Coords.). Derechos humanos de los grupos vulnerables, 2014, p.220-250. Disponível em: http://www.upf.edu/dhesalfa/materiales. Acesso em: 11/05/2015.

BURGORGUE-LARSEN, Laurence. El diálogo judicial. Máximo desafío de los tiempos jurídicos modernos. México: Porrúa, 2013.

; ÚBEDA DE TORRES, Amaya. The Inter-American Court of Human Rights: case law and commentary. Oxford, Oxford University Press, 2011.

DONNELLY, Jack. The Relative Universality of Human Rights. Human Rights Quarterly, v. 29, n. 2, 2007, p.281-306.

ESTUPIÑAN SILVA, Rosmerlin; IBÁÑEZ RIVAS, Juana María. La jurisprudencia de la Corte Interamericana de Derechos Humanos en materia de pueblos indígenas y tribales. In: BELTRÃO, Jane Felipe; BRITO FILHO, José Cláudio Monteiro de; GÓMEZ, Itziar; PAJARES, Emílio; PAREDES, Felipe; ZÚÑ̃IGA, Yanira (Coords.). Derechos humanos de 
los grupos vulnerables, 2014, p.316-356. Disponível em: http://www.upf.edu/dhesalfa/materiales. Acesso em: 15/05/2015.

FINKELSTEIN, Cláudio. Hierarquia das Normas no Direito Internacional. Jus Cogens $e$ Metaconstitucionalismo. São Paulo: Saraiva, 2013.

LAZARTE, Renata Bregaglio. ¿Verdadera indivisibilidad? Las consencias de las judicialización indirecta de los derechos económicos, sociales y culturales em el Sistema interamericano de derechos humanos. In: LOPES, Ana Maria D’Ávila; MAUÉS, Antonio Moreira. A eficácia nacional e internacional dos direitos humanos. Rio de Janeiro, Lumen Juris, 2013, p.257-290.

LOPES, Ana Maria D’Ávila. Discriminação de gênero contra as mulheres e a violência sexual. In: LOPES, Ana Maria D’Ávila; MAUÉS, Antonio Moreira. A eficácia nacional e internacional dos direitos humanos. Rio de Janeiro, Lumen Juris, 2013, p.15-26.

MANIGLIA, Elisabete. Direitos humanos: entre o relativismo e o universalismo. Ponderações e justificações das correntes em tempos hodiernos. In: LOPES, Ana Maria D’Ávila; MAUÉS, Antonio Moreira. A eficácia nacional e internacional dos direitos humanos. Rio de Janeiro, Lumen Juris, 2013, p.73-87.

PIOVESAN, Flávia. Direitos Humanos e o Direito Constitucional Internacional. 15a. ed. São Paulo: Saraiva.

PRESIDÊNCIA DA REPÚBLICA. SECRETARIA NACIONAL DE PROMOÇÃO DOS DIREITOS DA PESSOA COM DEFICIÊNCIA. SECRETARIA DE DIREITOS HUMANOS DA PRESIDÊNCIA DA REPÚBLICA. Avanços das Políticas Públicas para as Pessoas com Deficiência. Uma análise a partir das Conferências Nacionais. Brasília, 2012. Disponível em: http://www. pessoacomdeficiencia.gov.br/app/sites /default /files/publicacoes/livroavancos-politicas-publicas-pcd.pdf. Acesso em: 15/07/2015.

RAMOS, André de Carvalho. Processo internacional de direitos humanos. 4a. ed. São Paulo: Saraiva, 2015.

RELATÓRIO MUNDIAL SOBRE A DEFICIÊNCIA. GOVERNO DE SÃO PAULO. SECRETARIA DOS DIREITOS DA PESSOA COM DEFICIÊNCIA. Disponível em: http://www.Pessoacomdeficiencia.sp.gov.br/usr/share/documents/RELATORIO_MUNDIAL_ COMPLETO.pdf. Acesso em: 05/07/2015.

TEIXEIRA, Anderson Vichinkeski. Teoria Pluriversalista do Direito Internacional. São Paulo: Martins Fontes, 2011.

TEREZO, Cristina Figueiredo. Sistema Interamericano de Direitos Humanos: pela defesa dos direitos econômicos, sociais e culturais. Curitiba: Appris, 2014.

TRINDADE, Antonio Augusto Cançado. A Humanização do Direito Internacional. Belo Horizonte: Del Rey, 2006. 
Belo Horizonte: Del Rey, 2011.

. El Ejercicio de La Función Judicial Internacional.

Humanos. Porto Alegre: Sergio Antonio Fabris, 1997.

Tratado de Direito Internacional de Direitos - O Legado da Declaração Universal dos Direitos Humanos e sua Trajetória ao Longo das Seis Últimas Décadas (1948-2008). In: GIOVANNETTI, Andrea (Org.) 60 anos da declaração universal dos direitos humanos: conquistas do Brasil. Brasília: Fundação Alexandre de Gusmão, 2009. p.13-46.

Brasil. 2. ed. Brasília: Eunb, 2000.

. A proteção internacional dos direitos humanos e o

TRINDADE, Otávio Augusto Drummond Cançado. A Carta das Nações Unidas. Uma leitura constitucional. Belo Horizonte: Del Rey, 2012. 